UDC 378.37.004

DOI https://doi.org/10.31470/2415-3729-2021-13-278-290

\title{
Features of Education of Students-Philologists in the Conditions of Informatization and Digitalization of Higher Education
}

\section{Tetyana Sobchenko}

Doctor of Philosophy in Pedagogy (Ph.D), Associate Professor, Head of the Department of Education and Innovative Pedagogy, H.S. Skovoroda Kharkiv National Pedagogical University, $\triangle 29$ Alchevskykh Str., Kharkiv, Ukraine, 61002

E-mail: sobchenkotetyana79@gmail.com

ORCID: http://orcid.org/0000-0002-9213-5556

Date of receipt of the article: April 15, 2021 Article accepted for publication: June 02, 2021

\section{Особливості навчання студентів-філологів в умовах інформатизації та цифровізації вищої освіти}

\section{Тетяна Миколаївна Собченко}

кандидат педагогічних наук, доцент, доцент кафедри освітології та інноваційної педагогіки

Харківський національний педагогічний університет імені Г.С.Сковороди, $\bowtie$ вул. Алчевських, 29, м. Харків, Україна, 61002

Дата надходження статті: 15 квітня $2021 \mathrm{p}$. Стаття прийнята до друку: 02 червня 2021 p.

The article substantiates the relevance of informatization of society in general and education in particular, outlines the main tasks in the training of future professionals. The purpose of the article is to theoretically substantiate the peculiarities of the organization of the future philologists' training process. Methods. The following research methods are used: analysis and generalization of scientific and methodological sources, government documents on the research topic for the theoretical justification of the problem, modeling and synthesis of the obtained data. The results. The terminological apparatus «informatization of 
education», «means of informatization», «digitalization» is defined. The main components of the modern educational environment of a higher education institution are highlighted and the function of the innovative component is emphasized. It was found that the main components that will ensure the formation of digital competence of philology students are the content and means of education. It has been established that the study of compulsory and elective disciplines, which will contribute to the general and professional competencies' formation, is equally necessary for mastering the theoretical foundations and practical skills of using innovative information and digital technologies. It is established that within the obligatory course «Pedagogy» students of philological specialties master the module «Digital training tools» in which they gain basic knowledge about digital technologies and ways to use them, and hone and supplement this knowledge while studying other disciplines. In a classroom, students learn to use different computer-based learning tools to complete a variety of tasks. Future philologists search and critically analyze information on the Internet; work with electronic textbooks and dictionaries; prepare visual aids: presentations, tables, diagrams, infographics, briefings, create audio and video content for classes, prepare tasks for test control on various platforms and services, learn to present public information on social networks properly and more. Conclusions. It was found that in recent years there have been many philological sites that provide information assistance and various services, creating electronic libraries, virtual laboratories, Internet projects, which contribute to the quality of training of philological specialties students.

Key words: informatization, students of philology, digital technologies.

\section{References}

1. Tsyfrova adzhenta - Ukraina 2020 (2020)[ Digital Agent - Ukraine 2020] Retrieved from: https:/ucci.org.ua/uploads/ files/58e78ee3c3922.pdf1 [in Ukrainian].

2. Zakon Ukrainy pro vyshchu osvitu (2014) [Law of Ukraine on Higher Education]. Retrieved from: https://zakon.rada.gov.ua/laws/ show/1556-18\#Text [in Ukrainian].

3. Bratko, M. (2012) Struktura osvitnoho seredovyshcha vyshchoho navchalnoho zakladu. [The structure of the educational environment of higher education]. Naukovi zapysky Kirovohradskoho 
derzhavnoho pedahohichnoho universytetu imeni V.Vynnychenka. Seriia Pedahohichni nauky. - Scientific notes of Kirovohrad State Pedagogical University named after V. Vynnychenko. Pedagogical Sciences Series, 135, 67-72. [in Ukrainian].

4. Vashchenko L. (2012) Innovatsiine seredovyshche pisliadyplomnoi pedahohichnoi osvity. [Innovative environment of postgraduate pedagogical education]. Pisliadyplomna osvita - Postgraduate education, 1, 37-40 [in Ukrainian].

5. Zakon Pro Natsionalnu informatyzatsiiu osvity (1998). [Law on National Informatization of Education]. Retrieved from: https://zakon. rada.gov.ua/laws/show/74/98-\%D0\%B2\%D1\%80\#Text [in Ukrainian].

6. Krapliuk S.O. (2019) Osoblyvosti tsyfrovizatsii osvitnoho protsesu u vyshchii shkoli. Informatsiino-tsyfrovyi osvitnii prostir Ukrainy: transformatsiini protsesy i perspektyvy rozvytku. [Features of digitalization of the educational process in higher education. Information and digital educational space of Ukraine: transformation processes and prospects of development] Materialy metodolohichnoho seminaru NAPN Ukrainy. 4 kvitnia. - Proceedings of the methodological seminar of the National Academy of Pedagogical Sciences of Ukraine [in Ukrainian].

7. Sobchenko T. M.(2020) Zmishane navchannia yak zasib aktyvizatsii adaptyvnykh protsesiv u vyshchii pedahohichnii osviti. [Blended learning as a means of activating adaptive processes in higher pedagogical education] Elektronne naukove fakhove vydannia «Adaptyvne upravlinnia: teoriia i praktyka». Seriia «Pedahohika». - Electronic scientific professional publication «Adaptive control: theory and practice. Pedagogy Series, 9(17). Retrieved from: https:// amtp.org.ua/index.php/journal/article/view/340 [in Ukrainian].

8. Sobchenko T. M. (2020) Dosvid vykorystannia informatsiinokomunikatsiinykh tekhnolohii pry vykladannia pedahohichnykh dystsyplin. [Experience in the use of information and communication technologies in teaching pedagogical disciplines.] Visnyk Hlukhivskoho natsionalnoho pedahohichnoho universytetu. Pedahohichni nauky. - Bulletin of Glukhiv National Pedagogical University. Pedagogical Sciences. Vyp.44. S. 71-78. Retrieved from: https://drive.google. com/file/d/11PfxltTBL7L8NRQv00TueOHdGwrwBPPa/view [in Ukrainian]. 
9. Semenoh O. (2005) Systema profesiinoi pidhotovky maibutnikh uchyteliv ukrainskoi movy i literatury (v umovakh pedahohichnoho universytetu). [The system of professional training of future teachers of Ukrainian language and literature (in the conditions of pedagogical university)]. Doctor's thesis. Kyiv [in Ukrainian].

\section{Вступ}

Процес євроінтеграції неминуче торкається абсолютно усіх сфер життя нашого суспільства, однак, найсерйозніші зміни відбуваються у системі освіти. Вони стосуються іiі змісту, форм, засобів реалізації та інше. Тому у час стрімких перетворень як викладачам так і здобувачам слід не менш швидко реагувати на зміни, бути мобільним та пристосовуватись до інновацій. Паралельно iз згаданим процесом, відбувається активна інформатизація, що змінюється цифровізацією освіти та впливає на якість підготовки майбутніх фахівців. У «Цифровій адженті України - 2020» зазначено, що «...все, що може бути дигітизованим, має та буде дигітизованим» (Цифрова аджента, 2016).

Одна 3 провідних тенденцій професійної освіти спрямована на підготовку майбутніх фахівців нової генерації, які здатні до професійного саморозвитку, самореалізації, творчого пошуку, до вирішення нестандартних завдань, до прийняття науковообгрунтованих та виважених рішень, а також до орієнтації у інформаційному та цифровому суспільстві.

Особливої уваги заслуговує підготовка майбутнього філолога, оскільки саме філологічне знання, значення якого в духовному розвитку сучасного українського суспільства стрімко підвищується, має певну специфіку, що слід враховувати у організації процесу навчання.

Так, актуальні питання теоретико-методичної підготовки майбутніх філологів розкрито у роботах І. Клак, В. Коваль, М. Пригодія та ін. На окрему увагу заслуговують роботи дослідників В. Бабенко, О. Кучерявої, Н. Сорокіної, С. Костик, які присвячено формуванню дискурсивної, стилістичної та комунікативної, мовної та іншомовної компетентностей майбутніх фахівців філології. Способи використання інноваційних технологій та технічних ресурсів на заняттях та поза ними узагальнені науковцями Р.Дружененко, 
Н. Сердюк, І. Хрін, М. Шемудою та ін., обгрунтовано теоретикометодологічні й методичні засади навчання студентів-філологів в умовах інформатизації у наукових доробках Г. Алексєєвої, М. Байди, Р. Гуревич, С. Данилюк, С. Процької, Н. Сорокіної, Г. Шиліної.

На підставі викладеного встановлено, що підготовці філологів приділяється значна увага науковців, проте було визначено, що не достатньо розкрита проблема особливостей організації процесу навчання студентів філологічних спеціальностей в умовах інформатизації та цифровізації освіти.

Мета статті. Теоретично обгрунтувати особливості організації процесу навчання майбутніх філологів.

\section{Методи дослідження}

Серед використаних методів дослідження визначальними були такі: аналіз та узагальнення науково-методичних джерел, державних документів 3 теми дослідження задля теоретичного обгрунтування висвітлюваної проблеми, моделювання та синтезу отриманих даних.

\section{Результати та їх обговорення}

У процесі здобуття вищої освіти студенти опановують систематизовані знання, у них формуються уміння та навички, з'являються професійні якості, вибудовується система цінностей; вони оволодівають загальною культурою та низкою інших компетентностей. (Закон Про вищу освіту 2014).

За для досягнення завдань, які передбачає процес підготовки фахівців будь якої галузі, необхідно доцільно, грамотно, сучасно та перспективно планувати освітній процес. Лише за таких умов буде можливим зрощення спеціаліста, який на високому рівні володіє загальними та фаховими компетентностями.

Тому при створенні освітнього середовища, слід врахувати усі його компоненти, а саме: суб'єктний, ціннісно-цільовий, комунікативний, діяльністний, інформаційно-знаннєвий, ресурсний, інноваційний, організаційно-управлінський (Братко М. 2012).

У час реформування та інформатизації освіти, слід звернути особливу увагу саме на інноваційний компонент. Адже він забезпечує наповнення освітнього середовища інноваційним змістом та формами організації, надсучасними методами та засобами, створює потужний портал для інформаційних потоків та 
сприяє нарощуванню інноваційного потенціалу (Ващенко Л., Шапран О., Шапран Ю., 2012).

Під інформатизацією освіти розуміємо «...сукупність взаємопов'язаних організаційних, правових, політичних, соціально-економічних, науково-технічних, виробничих процесів, що спрямовані на створення умов для задоволення інформаційних потреб громадян та суспільства на основі створення, розвитку і використання інформаційних систем, мереж, ресурсів та інформаційних технологій, які побудовані на основі застосування сучасної обчислювальної та комунікаційної техніки...» (Закон про інформатизацію освіти, 1998).

Процес інформатизації нерозривно пов'язаний із застосуванням інноваційних технологій, які у свою чергу сприяють розвитку цифрової компетентності майбутніх спеціалістів. Остання являється обов'язковим результатом процесу підготовки студентів та набула особливої актуальності $з$ переходом університетів на вимушену змішану форму навчання.

Готуючи майбутніх педагогів: філологів, істориків, фахівців культури, вчителів початкових класів, мистецьких дисциплін та інших спеціалістів необхідно врахувати умови сьогодення та вимоги суспільства, щодо володіння теоретичними основами цифрової грамотності; практичними уміннями застосовувати різноманітні технічні засобів за призначенням; навичками роботи 3 різними інформаційними ресурсами, хмарними технологіями.

Забезпечити зазначені теоретичні знання та практичні навички дозволить зміст навчальної програми та засоби навчання.

У Законі України «Про національну програму інформатизації» (1998 зі змінами) зазначено, що такими засобами являються «...програмне, математичне, лінгвістичне та інше забезпечення, інформаційні системи або їх окремі елементи, інформаційні мережі і мережі зв'язку, що використовуються для реалізації інформаційних технологій...» (Закон про інформатизацію освіти, 1998).

На зміну епохи інформатизації «стрибкоподібно» прийшла цифровізація, що дозволила зробити гігантські кроки уперед. У науковій літературі існує чимало тлумачень дефініції «цифровізація». Наукова спільнота розглядає «цифровізацію» як «цифровий спосіб 
зв’язку, запису, передачі даних з допомогою цифрових пристроїв» (С. Карплюк, 2019). На основі аналізу та узагальнення наукових доробок, було зроблено висновок та прийнято рішення автора під цифровізацією слід розуміти спосіб цифрового подання та обміну інформації за допомогою цифрових інструментів.

На думку С. Карплюка, цифровізація сприяє спрощенню освітнього процесу, оскільки робить його біль гнучким та пристосованим до сучасних реалій (С.Карплюк, 2019).

Щодо змісту навчання, то найсучасніші освітні програми передбачають обов'язкові самостійні або інтегровані дисципліни, на яких студенти знайомляться 3 цифровими технологіями та розглядають шляхи їх використання в залежності від майбутньої професійної діяльності.

Так, до освітньої програми майбутніх філологів в останні роки внесено інтегрований курс 3 педагогіки, до нього включено модуль «Засоби цифрової підготовки», у рамках якого опановують зміст інформаційно-цифрової компетентності майбутнього філолога, досліджують засоби інформатизації освіти; вивчають мережеві освітні технології, знайомляться 3 основами інформаційної безпеки; засвоюють поняття інформаційноосвітнє середовище та принципи його створення, навчаються правильно візуалізувати навчальний матеріал, досліджують базові принципи мобільного, дистанційного та змішаного навчання, переваги та недоліки таких форм навчання та інше.

У попередніх авторських доробках наголошується увага на тому, що у процесі підготовки здобувачів філологічних спеціальностей слід організувати відповідне освітнє середовище, яке містить інформаційну, інтерактивну та цифрову складову (Собченко Т., 2020).

У рамках циклу загальної та професійної підготовки студентів-філологів, викладачі активно застосовують технічні засоби навчання та спонукають студентів до їх використання, особливо для підготовки домашніх завдань, при виконанні індивідуальних завдань та на практичних і семінарських заняттях. Адже, не зважаючи, на те, що майбутній філолог - це фахівець гуманітарного циклу дисциплін він повинен вміти використовувати інноваційні інформаційні технології. 
Найпоширенішим видом роботи $є$ пошук інформації в мережі «Інтернет». За для цього, студент повинен не просто вміти користуватися технічним засобом для входу до мережі, а й розуміти різницю та можливості відображення інтерфейсу ресурсу в залежності від обраного типу гаджету. Окрім цього, студенти повинні критично підходити до відбору необхідної інформації, у разі ії використання для науководослідної роботи не забувати про академічну доброчесність.

Говорячи про опрацювання знайденої в мережі інформації, неможливо не згадати пошук словників та роботу з ними. Принципи роботи 3 електронними словниками такий же самий, як і 3 паперовими, та має ряд очевидних переваг: швидкість, доступність, можливість обробки великого об'єму інформації. Теж саме можна сказати й про електронні підручники, адже не завжди книги, словники та інші засоби навчання $є$ у достатній кількості у бібліотеках та на кафедрах.

В умовах інформатизації освітнього процесу усе більше 3'являється можливостей забезпечити необхідними навчальними засобами студентів, легко та швидко передавати та поширювати їх. Уміння працювати 3 електронними носіями інформації вкрай необхідні майбутнім філологам для професійної діяльності у майбутньому.

Окрему увагу слід звернути на унаочнення навчального матеріалу. Цей процес відбувається як з боку викладачів, які фактично демонструють зразок правильного унаочнення з урахуванням усіх принципів, так і з боку студентів, які продукують власні розробки на заняттях наслідуючи зразок педагогів. Це можуть бути презентація, інфографіка, схема, таблиця, інформаційний інструктаж та інше. В умовах змішаного навчання такі навички $є$ невід'ємною частиною професійної майстерності спеціаліста.

Необхідним є не лише візуальний супровід занять, про який згадано вище, а й уміння створювати та відбирати доцільний аудіо та відео контент, що значно полегшує сприймання теорії, дозволяє порівнювати різні підходи вирішення проблемних ситуації, виявити помилки та неточності.

3 метою перевірки знань майбутніх філологів, педагоги самостійно розробляють різні види контролю, використовуючи при цьому хмарні технології, та навчають цьому студентів. 
Так для функції контролю, найдоцільнішими є використання Google форми, платформи Moodle, сервісу Kahoot та інших технологій. 3 ними студенти знайомляться у рамках курсів спрямованих на формування цифрової компетентності. Вдосконалюють свої знання та застосовують їх на практиці під час вивчення дисциплін, спрямованих на формування загальних та фахових компетентностей.

Для майбутніх філологів в умовах інформатизації суспільства необхідно вміти себе самопрезентувати. Саме тому для студентів необхідно оволодіти культурою ведення соціальних мереж та блогів.

У рамках обов'язкових або вибіркових курсів студенти отримують теоретичну базу, щодо правил ведення власної сторінки. Для філолога надважливо публікувати лише перевірений контент, не порушувати норм моралі, демонструвати високий рівень володіння загальною культурою. Усе це допоможе у майбутньому створити власний позитивний імідж.

За останні роки мережа «Інтернет» стала досить насичена філологічними сайтами. Активно працюють різні інтернет проекти, надають окремі послуги (перевірка, переклад, транслітерація та інше) мережеві сервіси, продуктивно функціонують он-лайн студії вивчення мови. При університетах створюються електронні бібліотеки, віртуальні лабораторії (Семеног О., 2002)

Час та технології не стоять на місці, тому у XXI столітті студенти будь-якого фаху повинні досконало володіти цифровими технологіями, а головне уміти їх застосовувати у практичній діяльності. Це значно підвищить їх професіоналізм та відкриє більше можливостей для професійної самореалізації.

Тому закладам вищої освіти, необхідно враховувати цифрову компетентність викладачів та шукати шляхи iіi підвищення; регулярно переглядати зміст освітніх програм відповідно до змін у змісті освіти; дбати про сучасне та доступне матеріально-технічне забезпечення. Лише за таких умов заклади вищої освіти зможуть готувати фахівців, що відповідають європейським стандартам та «епосі» диджіталізації.

\section{Висновки}

У період інформатизації та цифровізації освіти, слід ретельно та «індивідуально» підходити до процесу підготовки 
майбутніх фахівців кожної спеціальності. Особливо гостро це питання постало при підготовці студентів філологів, у освітню програму яких тривалий час не було включено достатньої кількості дисциплін, що сприяють формуванню цифрової компетентності, недостатньо володіли нею і викладачі. Однак, активний процес цифровізації освіти та змішане навчання в умовах карантину внесли позитивні корективи. Тому такі важливі та необхідні для майбутніх філологів навички використання інформаційних технологій почали активно вдосконалюватись, тим самим підвищився рівень їх загальної та фахової підготовки Вважаємо за потрібне регулярно переглядати та вдосконалювати зміст, форми, методи та засоби, що використовуються при підготовці студентів філологів. Перспективою подальших досліджень вбачаємо вивчення впливу окремих дисциплін, на яких активно застосовуються інформаційні та цифрові технології, оскільки це впливає на якість засвоєння навчального матеріалу.

\section{Література}

1. Цифрова аджента - Україна 2020 Режим доступу: URL: https:/ucci.org.ua/uploads/files/58e78ee3c3922.pdf1.

2. Закон Про освіту URL: https://zakon.rada.gov.ua/laws/ show/1556-18\#Text

3. Братко М. Структура освітнього середовища вищого навчального закладу. Наукові записки Кіровоградського державного педагогічного університету імені В.Винниченка. Серія Педагогічні науки. 2012, Вип.135. С. 67-72.

4. Ващенко Л. Інноваційне середовище післядипломної педагогічної освіти. Післядипломна освіта. 2012. № 1. С. 37-40.

5. Закон Про Національну інформатизацію освіти URL: https:// zakon.rada.gov.ua/laws/show/74/98-\%D0\%B2\%D1\%80\#Text

6. Краплюк С.О. Особливості цифровізації освітнього процесу у вищій школі. Інформаційно-цифровий освітній простір України: трансформаційні процеси і перспективи розвитку. Матеріали методологічного семінару НАПН України. 4 квітня 2019 р. / За ред. В.Г. Кременя, О.І. Ляшенка; укл. А.В. Яцишин, О.М. Соколюк. К, 2019. $361 \mathrm{c}$.

7. Собченко Т. М. Змішане навчання як засіб активізації адаптивних процесів у вищій педагогічній освіті. Електронне наукове 
фахове видання «Адаптивне управління: теорія і практика. Серія «Педагогіка», Випуск 9(17), 2020. URL: https://amtp.org.ua/index. $\mathrm{php} /$ journal/article/view/340

8. Собченко Т. М. Досвід використання інформаційнокомунікаційних технологій при викладання педагогічних дисциплін. Вісник Глухівського національного педагогічного університету Педагогічні науки, Вип.44, 2020. С. 71-78. URL:: https://drive.google.com/file/d/11PfxltTBL7L8NRQv00TueOHdGwr wBPPa/view

9. Семеног О. Система професійної підготовки майбутніх учителів української мови і літератури (в умовах педагогічного університету). дис. ... док.пед.наук 13.00.04 / Київ. 2005.476с.

\section{Собченко Т.М.}

\section{Особливості навчання студентів-філологів в умовах інформатизації та цифровізації вищої освіти}

У статті обгрунтовано актуальність інформатизації суспільства уцілому та освіти зокрема, окреслено коло основних завдань при підготовці майбутніх фахівців. Визначено термінологічний апарат «інформатизація освіти», «засоби інформатизації», «цифровізація». Виділено основні компоненти сучасного освітнього середовища закладу вищої освіти та підкреслено функцію інноваційного компоненту. 3'ясовано, що основними компонентами, які забезпечуватимуть формування цифрової компетентності студентів-філологів $€$ зміст та засоби освіти. Установлено, що вивчення обов'язкових та елективних дисциплін, що сприятимуть формуванню загальних та фахових компетентностей, $є$ однаково необхідним для оволодіння теоретичними основами та практичними навичками використання інноваційних інформаційних та цифрових технологій.

Встановлено що в рамках обов'язкового курсу «Педагогіка» студенти філологічних спеціальностей опановують модуль «Засоби цифрової підготовки» у рамках якого отримують базові знання щодо цифрових технологій та шляхів їх використання, а відшліфовують та поповнюють ці знання під час вивчення решти навчальних дисциплін. На заняттях, під час виконання різного 
виду завдань студенти вчаться застосовувати різні комп’ютерні засоби навчання.

Майбутні філологи займаються пошуком та критичним аналізом інформації в мережі «Інтернет»; працюють з електронними підручниками та словниками; готують унаочнення навчального матеріалу: презентації, таблиці, схеми, інфографіки, інструктажі, створюють аудіо та відео контент для занять, готують завдання для тестового контролю на різних платформах та сервісах, навчаються правильно презентувати публічну інформацію у соціальних мережах та інше.

3'ясовано, що останні роки з'явилося багато філологічних сайтів, які представляють інформаційну допомогу та різного виду послуги, створюються електронні бібліотеки, віртуальні лабораторії, інтернет проекти, що сприяє якісній підготовці студентів філологічних спеціальностей.

Ключові слова: інформатизація, студенти-філологи, цифрові технології.

\section{Собченко Т.Н.}

\section{Особенности обучения студентов-филологов в условиях ин- форматизации и цифровизации высшего образования}

\section{Аннотация}

В статье обоснована актуальность информатизации общества вцелом и образования в частности, определен круг основных задач при подготовке будущих специалистов. Определены терминологический аппарат «информатизация образования», «средства информатизации», «цифровизация». Выделены основные компоненты современной образовательной среды учреждения высшего образования и подчеркнуто функцию инновационного компонента. Установлено, что основными компонентами, которые будут обеспечивать формирование цифровой компетентности студентов-филологов смысл и средства образования. Установлено, что изучение обязательных и элективных дисциплин, способствующих формированию общих и профессиональных компетенций, одинаково необходимым для овладения теоретическими основами и практиче- 
скими навыками использования инновационных информационных и цифровых технологий.

Установлено, что в рамках обязательного курса «Педагогика» студенты филологических специальностей овладевают модулем «Средства цифровой подготовки» в рамках которого получают базовые знания по цифровым технологиям и пути их использования, шлифуют и пополняют эти знания при изучении остальных учебных дисциплин. На занятиях, при выполнении различного вида заданий студенты учатся применять различные компьютерные средства обучения.

Будущие филологи занимаются поиском и критическим анализом информации в сети «Интернет»; работают с электронными учебниками и словарями; готовят иллюстрации учебного материала: презентации, таблицы, схемы, инфографики, инструктажи, создают аудио и видео контент для занятий, готовят задания для тестового контроля на различных платформах и сервисах, учатся правильно презентовать публичную информацию в социальных сетях и прочее.

Выяснено, что в последние годы появилось много филологических сайтов, которые представляют информационную помощь и разного вида, услуги, создаются электронные библиотеки, виртуальные лаборатории, интернет проекты, что способствует качественной подготовке студентов филологических специальностей.

Ключевые слова: информатизация, студенты-филологи, цифровые технологии. 